\title{
Perancangan dan Implementasi Presensi Digital Guru dan Karyawan SMA Negeri 9 Semarang
}

\author{
Th. Didot Septiawan ${ }^{1)}$, Rinta Kridalukmana ${ }^{2)}$, Ike Pertiwi Windasari ${ }^{2)}$ \\ Program Studi Sistem Komputer, Fakultas Teknik, Universitas Diponegoro \\ Jalan Prof. Sudharto, Tembalang, Semarang, Indonesia
}

\begin{abstract}
Abstrak - Berdasarkan surat edaran dari Kepala Dinas Pendidikan Kota Semarang, terhitung mulai Januari 2015 tiap sekolah dihimbau untuk beralih dari sistem presensi manual menjadi digital. Hingga awal Maret ini, presensi guru dan karyawan di SMA Negeri 9 Semarang masih dilakukan secara manual. Maka diperlukan sebuah penelitian untuk merancang dan menerapkan sistem presensi digital bagi SMA Negeri 9 Semarang.

Tahapan penelitian meliputi perencanaan, analisis, perancangan, implementasi, pengujian, dan pemeliharaan. Perangkat lunak dibangun dengan framework PHP Phalcon, basis data MySQL, dan aplikasi webserver Nginx pada sistem operasi Ubuntu 14.04. Mesin presensi dengan metode pengenalan wajah dipilih untuk mendapatkan data kehadiran yang bersifat autentik. Pengujian dilakukan dengan metode kotak hitam dan kotak putih.

Semua kebutuhan fungsional telah diimplementasikan pada aplikasi web dan kebutuhan non-fungsional pun telah terpenuhi. Sistem presensi digital ini menjadi solusi bagi SMA Negeri 9 Semarang dalam usaha uji coba penggunaan presensi digital.
\end{abstract}

Kata kunci - Sistem Presensi Digital, PHP, Phalcon, MySQL, Nginx, Ubuntu, kotak hitam, kotak putih

\section{PENDAHULUAN}

Aplikasi berbasis web banyak digunakan sebagai media komunikasi melalui internet karena memiliki keunggulan dalam hal fleksibilitas. Bahkan saat ini aplikasi sistem informasi berbasis web juga telah mulai merambah dunia pendidikan. Di bidang pendidikan, aplikasi berbasis web telah banyak digunakan sebagai sarana penyampaian informasi antar instansi pendidikan.

Proses presensi guru dan karyawan di SMA Negeri 9 Semarang masih menggunakan metode tanda tangan. Sistem tersebut berjalan dengan baik dan tidak terdapat keluhan dari pihak pelaksana. Namun berdasarkan surat edaran dari Kepala Dinas Pendidikan Kota Semarang, terhitung mulai Januari 2015 tiap sekolah dihimbau beralih dari sistem presensi tanda tangan menjadi digital.

Presensi digital menawarkan keunggulan dalam proses pengolahan data dan penyajian informasi yang lebih cepat. Namun untuk menikmati teknologi yang sedemikian rupa diperlukan proses transisi yang tidak mudah. Peralihan dari kondisi manual menuju digital memerlukan proses adaptasi dari pihak pengguna. Merupakan hal yang wajar apabila pengguna sistem baru ingin berhenti dan menggunakan kembali sistem lama yang lebih akrab digunakan. Untuk itu, sistem yang baru perlu memberikan kemudahan dalam hal pemakaian.

Selain daripada perangkat lunak itu sendiri, dukungan perangkat keras juga diperlukan dalam membangun suatu sistem. Tantangan dalam dunia digital adalah bagaimana cara untuk mendapatkan data yang autentik. Oleh sebab itu, komponen input yang digunakan sangat menentukan keabsahan dari presensi digital. SMA Negeri 9 Semarang memiliki mesin presensi digital Fingerspot FacePro 200 dengan fasilitas RFID dan pengenalan wajah yang reliabel namun belum dimanfaatkan untuk presensi sehari-hari.

Berdasarkan latar belakang tersebut, dapat dirumuskan permasalahan yang berusaha diselesaikan dalam penelitian ini yaitu, "Bagaimana merancang dan menerapkan sebuah sistem presensi digital yang dapat menampilkan data kehadiran melalui aplikasi berbasis web dan memberikan kemudahan bagi SMA Negeri 9 Semarang dalam membuat laporan presensi?".

Tujuan dari penelitian tugas akhir ini adalah merancang sebuah sistem presensi digital bagi guru dan karyawan, dan mengimplementasikan hasil rancangan tersebut di SMA Negeri 9 Semarang dengan memanfaatkan sarana dan prasarana yang dimiliki oleh SMA Negeri 9 Semarang. Untuk menghindari pembahasan yang meluas maka ditetapkan batasan-batasan berikut :

1. Sistem presensi digital ini diharapkan dapat : mengelola data guru dan karyawan SMA Negeri 9 Semarang, mencatat data kehadiran secara digital namun bersifat autentik, menampilkan waktu kehadiran, dan menghasilkan laporan presensi.

2. Perangkat keras yang digunakan merupakan bagian dari sarana dan pra-sarana yang dimiliki oleh SMA Negeri 9 Semarang.

3. Perangkat lunak dibangun menggunakan bahasa skrip PHP dan mengikuti susunan kerangka kerja PHP Phalcon, menggunakan basis data MySQL, webserver Nginx, dalam lingkungan sistem operasi Ubuntu 14.04.

4. Tidak dilakukan pembahasan mengenai teknologi dan metode identifikasi : pengenalan wajah, sidik jari, dan sebagainya. 


\section{KAJIAN PUSTAKA}

\section{A. Kajian Hasil Penelitian Terdahulu}

Andrika merancang aplikasi berbasis web sebagai presensi digital STMIK Atma Luhur Pangkalpinang. Pengguna aplikasi ditujukan untuk dosen dan tata usaha yang login sebagai admin. Proses identifikasi masih secara manual: dosen memulai kegiatan perkuliahan, mengakses aplikasi, memeriksa kehadiran mahasiswa di dalam kelas, dan kemudian memberikan masukan (klik pada nama mahasiswa dalam daftar hadir) pada halaman web. Aplikasi dirancang menggunakan paket XAMPP yang terdiri dari webserver Apache, basis data MySQL, PHP dan PHPMyAdmin. Program bantu yang digunakan adalah Macromedia Dreamweaver 8 dan Adobe Photoshop. ${ }^{[1]}$

Muhammad merancang aplikasi berbasis web untuk melengkapi presensi digital ITS Surabaya yang sudah menggunakan identifikasi sidik jari. Mesin presensi merekam kehadiran dosen dan mahasiswa dalam kegiatan perkuliahan, sedangkan aplikasi bertugas memilah data presensi yang valid dan kemudian menyimpannya dalam basis data server. Webserver yang dipakai adalah Apache, dengan basis data MySQL dan Microsoft SQL Server Management Studio. Bahasa pemrograman yang dipakai adalah PHP dengan kerangka kerja CodeIgniter. Program bantu yang dipakai adalah Netbeans 7 dan JDK 6 + Set Environtment. ${ }^{[2]}$

Subair mengembangkan sistem presensi digital milik STMIK AMIKOM Yogyakarta yang masih menggunakan kartu RFID. Sistem yang baru menggunakan identifikasi sidik jari dan merekam kehadiran mahasiswa dalam kegiatan perkuliahan. Pengguna aplikasi ditujukan pada tata usaha yang melakukan login sebagai admin. Basis data yang digunakan adalah MS Access dengan menggunakan program bantu PHPMyAdmin. Basis aplikasi adalah desktop dan bahasa pemrograman yang digunakan adalah VB dengan lingkungan pengembangan Visual Basic 6. ${ }^{[3]}$

\section{B. Sistem Presensi}

Presensi digital menawarkan apa yang tidak dimiliki oleh presensi manual dalam hal batasan waktu dan menutupi kekurangan dari presensi semi-manual dalam pengelolaan data. Kekurangan dari presensi digital adalah diperlukannya mesin presensi digital yang tidak murah untuk mendapatkan performa identifikasi sidik jari / wajah yang reliabel.

\section{Sistem Informasi}

SI merupakan kumpulan sub-sub sistem baik fisik maupun non-fisik yang saling berhubungan satu sama lain dan bekerja sama secara harmonis untuk mencapai satu tujuan yaitu mengolah data menjadi informasi yang berguna. ${ }^{[4]}$

\section{D. $P H P$}

PHP (PHP Hypertext Pre-processor) merupakan bahasa pemrograman skrip sisi server yang tertanam dalam HTML dan berguna dalam membuat aplikasi web. Dengan PHP dimungkinkan pengembangan web dengan isi dinamis, pengelolaan basis data, pelacakan sesi, bahkan membangun sebuah situs web secara keseluruhan. ${ }^{[5]}$

\section{E. Phalcon PHP Framework}

Phalcon adalah kerangka kerja PHP bersifat open-source, dibangun dengan ekstensi dari $\mathrm{C}$ dan mengadopsi prinsip orientasi objek. Pengguna tidak perlu menguasai bahasa $\mathrm{C}$ untuk menggunakan Phalcon, karena semua fungsi telah disajikan dalam bahasa PHP. ${ }^{[6]}$

Phalcon menawarkan kelas berorientasi objek yang diperlukan dalam implementasi arsitektur MVC pada sebuah aplikasi. Pola desain MVC banyak digunakan oleh kerangka kerja web dan aplikasi desktop. ${ }^{[7]}$

\section{F. MySQL}

Saat ini RDBMS telah banyak digunakan untuk menyimpan dan mengelola data yang berjumlah sangat besar. Dinamakan basis data relasi karena semua data yang tersimpan ditempatkan pada beberapa tabel berbeda dan terdapat relasi yang bertugas menghubungkan data dari suatu tabel ke data pada tabel yang lain menggunakan primary keys dan foreign keys. ${ }^{[8]}$

\section{G. Webserver Nginx}

Nginx (dalam bahasa Inggris Engine-x) merupakan salah satu dari beberapa server yang dirancang untuk menjawab masalah C10K. Tidak seperti server tradisional, Nginx tidak bergantung konsep threads dalam menangani permintaan. Sebaliknya, Nginx menggunakan arsitektur berbasis event (asynchronous) yang lebih scalable. Arsitektur ini menggunakan memori kecil, namun yang lebih penting, jumlah memori under load dapat diprediksi. ${ }^{\text {[9] }}$

\section{H. PHP - Curl}

Fungsi dari PHP-Curl dapat digunakan untuk mengambil data kehadiran dari mesin presensi digital tanpa menggunakan web browser. Contoh senarai program PHP-Curl tersebut diunggah oleh Aguno ${ }^{[10]}$ pada halaman Github, dan juga oleh Iserni dan Sheraff ${ }^{[11]}$ pada halaman Stackoverflow.

\section{I. $U M L$}

UML (Unified Modelling Language) adalah bahasa standar dalam menentukan spesifikasi, membangun, memberikan gambaran, dan mendokumentasikan sistem perangkat lunak. Tidak hanya terbatas pada pemodelan perangkat lunak, UML juga digunakan untuk memodelkan aliran proses dalam kegiatan produksi, tata cara penggunaan, serta proses bisnis dari perusahaan. ${ }^{[12]}$

\section{J. JQuery}

JQuery dirancang untuk menyederhanakan task dengan menulis sedikit kode. Beberapa fitur utama dari jQuery adalah: DOM manipulation, event handling, AJAX support, animations, lightweight, dan cross browser support. ${ }^{[13]}$

\section{K. Bootstrap}

Bootstrap merupakan kerangka paling populer dalam desain HTML, CSS, dan JS untuk mengembangkan web yang responsif, dan kompatibel dengan perangkat mobile. ${ }^{[14]}$ 


\section{Model Air Terjun (Waterfall)}

SDLC (Software/System Development Life Cycle) memiliki beberapa macam model dalam penerapan tahapan proses, salah satu yang paling sederhana adalah model air terjun (waterfall). Model air terjun ini hanya cocok untuk mengembangkan perangkat lunak dengan spesifikasi yang tidak berubah-ubah. ${ }^{[15]}$

\section{Pengujian Perangkat Lunak}

pengujian perangkat lunak (bahasa Inggris: software testing) merupakan suatu investigasi yang dilakukan untuk mendapatkan informasi mengenai kualitas dari produk atau layanan yang sedang diuji (under test). ${ }^{[16]}$

1) Pengujian Black Box : Tanpa perlu pengetahuan tentang bagian internal dan cara kerja aplikasi dari dalam, penguji hanya paham dengan tujuan dan manfaat sistem. Tanpa melihat senarai kode program, penguji memberi data masukan dan memeriksa data keluaran. ${ }^{[17]}$

2) Pengujian White Box : Pengujian white box adalah penyelidikan rinci dari logika internal dan struktur kode dalam senarai program. Pengujian white box disebut juga pengujian kaca atau pengujian kotak terbuka. ${ }^{[18]}$

\section{PERANCANGAN}

\section{A. Sistem yang Berjalan}

Proses presensi guru dan karyawan di SMA Negeri 9 Semarang masih dilakukan secara manual. Presensi dilakukan dengan membubuhkan tanda tangan pada sebuah lembaran kertas. Sistem berjalan dengan baik namun sulit untuk memastikan bahwa setiap guru dan karyawan hadir dan pulang tepat waktu. Data yang terdapat pada lembar presensi tersebut adalah :

- Kepala dokumen, berisikan nama dan logo instansi, serta judul dokumen;

- Tabel kehadiran, berisikan kolom nama dan NIP pegawai, serta kolom tanggal kerja dalam kurun waktu 1 bulan yang nantinya ditandatangani oleh pegawai;

- Keabsahan dokumen, berupa tanda tangan kepala instansi, dibubuhi stempel.

\section{B. Sistem yang Diharapkan}

Hasil diskusi dengan Kepala Sekolah digunakan sebagai acuan dalam menentukan informasi apa saja yang perlu disajikan oleh sistem.

Hasil keluaran utama yang diharapkan dari Sistem Presensi Digital SMA Negeri 9 Semarang adalah laporan presensi yang serupa dengan dokumen presensi manual yang berjalan, hanya saja tanda kehadiran pegawai bukan berupa tanda tangan melainkan informasi waktu hadir dan pulang.

Selanjutnya diperlukan beberapa analisis kebutuhan untuk menentukan hal-hal lain yang perlu ditangani oleh sistem dalam usaha memenuhi tujuan utama yang ingin dicapai.

1) Kebutuhan Data : Sistem dapat menerima, menyimpan, memproses, dan menyajikan data nomor identitas, data karyawan, data kehadiran, data login.
2) Kebutuhan Jenis Pengguna : Pengguna Sistem Presensi Digital SMA Negeri 9 Semarang adalah karyawan, tata usaha, karyawan, dan pengunjung web.

3) Kebutuhan Fungsional : Pernyataan dari hal-hal yang harus dilakukan sistem, layanan yang diberikan, dan fungsi utama yang harus dimiliki, ditunjukkan pada Tabel 1 .

TABEL I

KEBUTUHAN FUNGSIONAL

\begin{tabular}{|l|l|}
\hline Fungsi & Deskripsi \\
\hline Presensi digital & Verifikasi kehadiran mesin presensi digital \\
\hline Lihat presensi & Menyajikan tabel data presensi \\
\hline Lihat Rekap & Menyajikan tabel data rekap \\
\hline Login dan Logout & Verifikasi Login dan Logout \\
\hline Lihat data karyawan & Menampilkan tabel karyawan \\
\hline Kelola data karyawan & Masukan data baru / ubah / hapus karyawan \\
\hline Ubah status karyawan & Status aktif/pindah/pensiun pada karyawan \\
\hline Import data karyawan & Tambah / ubah beberapa data karyawan \\
\hline Unduh data karyawan & File xls untuk diunduh oleh Tata Usaha \\
\hline Pembaruan presensi & Unduh data kehadiran dari mesin presensi \\
\hline Hapus data presensi & Hapus data presensi dalam basis data server \\
\hline Laporan PDF & Penyajian presensi dalam format PDF \\
\hline
\end{tabular}

4) Kebutuhan Non-Fungsional : Tidak terkait secara langsung dengan tujuan dan manfaat sistem, memberi batasan pada kebutuhan fungsional, ditunjukkan pada Tabel 2.

TABEL II

KEBUTUHAN NON-FUNGSIONAL

\begin{tabular}{|l|l|}
\hline Nama & Deskripsi \\
\hline Hak akses & Hak akses sesuai jenis pengguna \\
\hline Praktis & Mudah, dapat digunakan oleh pihak awam \\
\hline Sederhana & Tidak perlu animasi yang berlebihan \\
\hline Teknik penyajian & Penyajian data mudah dipahami \\
\hline Aplikasi rekap & Aplikasi android untuk kepala sekolah \\
\hline
\end{tabular}

5) Kebutuhan Antarmuka : Tampilan web dengan tombol login-logout dan mепи-bar untuk halaman home, login, presensi (indeks, tabel), laporan pdf, rekap (indeks, tabel), karyawan (index, status, import), halaman pembaruan dan hapus presensi.

\section{Perancangan Basis Data}

1) ERD (Entity Relationship Diagram) : Merupakan pemodelan awal dari basis data yang banyak digunakan untuk basis data relasional, ditunjukkan pada Gambar 1.

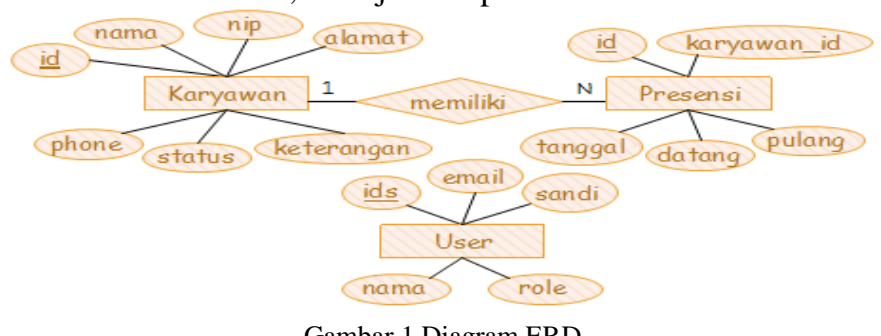

Gambar 1 Diagram ERD 
2) CDM (Conceptual Data Model) : Merupakan hasil penjabaran lanjut ERD dengan gambaran konsep terkait pandangan pemakai terhadap data yang disimpan pada basis data, ditunjukkan pada Gambar 2.
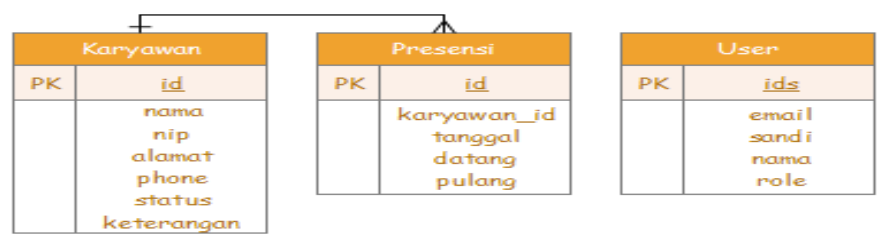

Gambar 2 Diagram CDM

3) PDM (Physical Data Model) : Merupakan model fisik dari perancangan tabel dalam basis data, setiap tabel memiliki kolom (attribut) nama bersifat unik beserta tipe datanya, ditunjukkan pada Gambar 3.

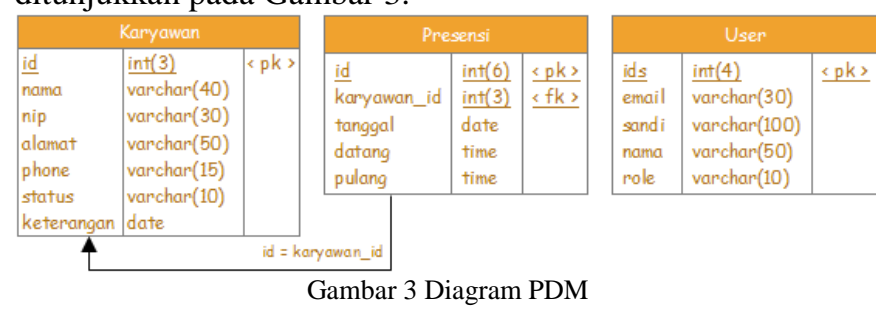

D. Struktur Menu Berdasarkan Hak Akses Pengguna 1) Karyawan / Pengunjung: Ditunjukkan pada Gambar 4.

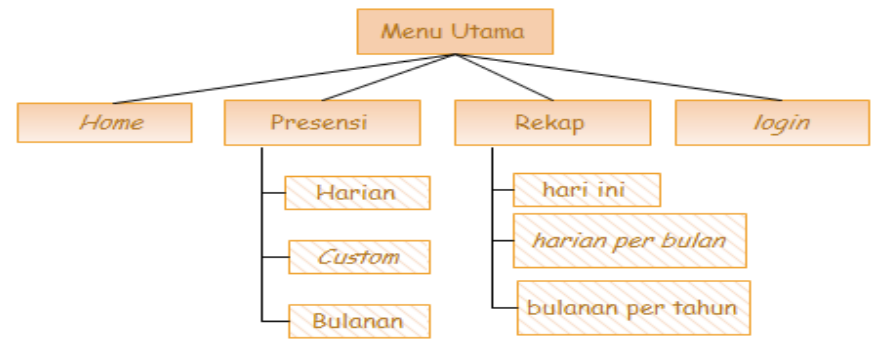

Gambar 4 Struktur menu untuk karyawan/pengunjung

2) Tata Usaha : Ditunjukkan pada Gambar 5.

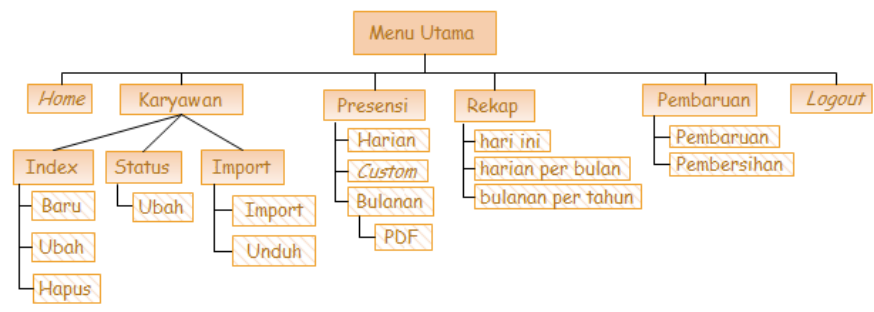

Gambar 5 Struktur menu untuk tata usaha

\section{E. Model dari Perilaku Sistem}

1) Diagram Use Case : Interaksi antara pengguna dan sistem sesuai dengan kebutuhan fungsional yang telah ditetapkan sebelumnya, terlihat seperti pada Gambar 6 .

2) Diagram Aktivitas : Aktivitas sistem saat pengunjung mengakses web ditunjukkan pada Gambar 7 sedangkan aktivitas sistem saat tata usaha mengakses web ditunjukkan pada Gambar 8 .

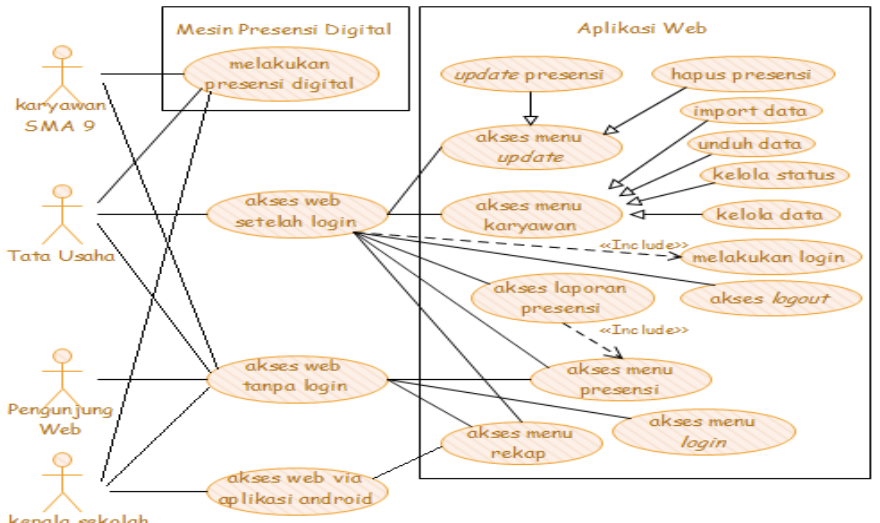

Gambar 6 Diagram use case

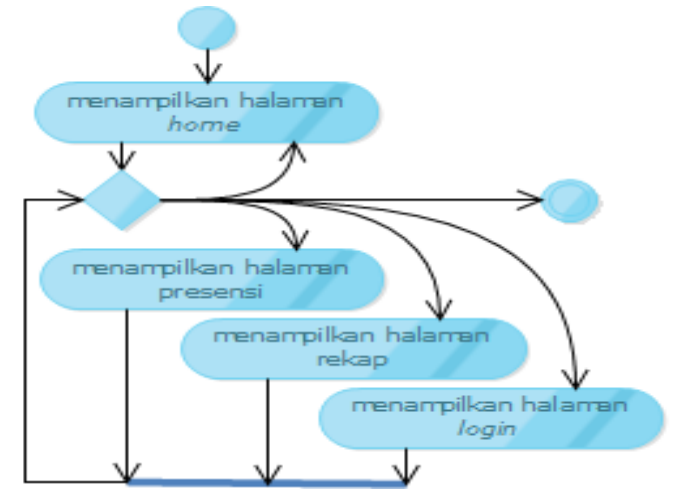

Gambar 7 Diagram aktivitas saat pengunjung mengakses web

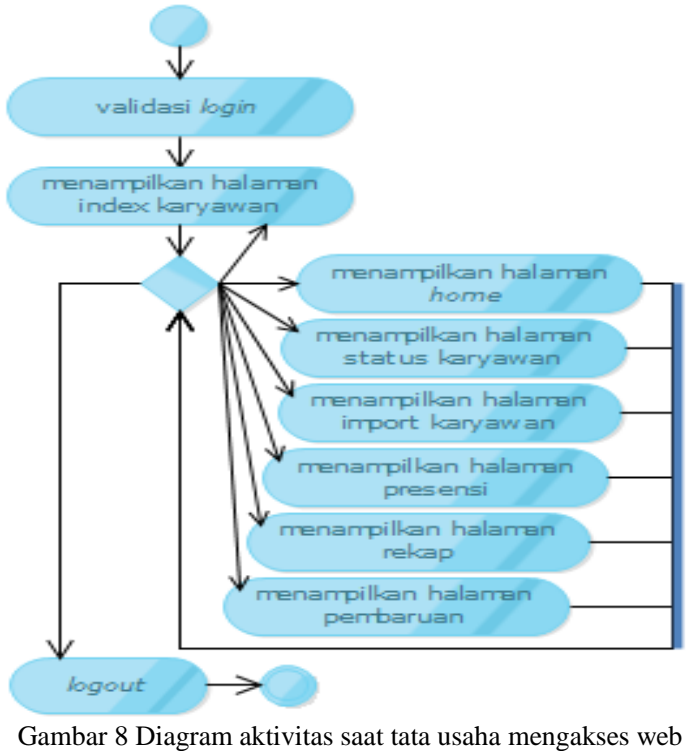

\section{F. Model dari Struktur Sistem}

Diagram kelas merupakan salah satu pemodelan UML yang berfungsi untuk menggambarkan struktur statis dari sebuah sistem. Aplikasi web sistem presensi SMA Negeri 9 Semarang mengikuti konsep MVC (model, view, controller).

Kelas model merupakan gambaran dari basis data, view merupakan gambaran dari tampilan, dan controller diambil dari pendefinisian use case. Diagram kelas dari aplikasi web sistem presensi digital SMA Negeri 9 Semarang ditunjukkan pada Gambar 9. 


\section{IMPLEMENTASI DAN PENGUJIAN}

\section{A. Gambaran Umum Sistem}

Sistem presensi digital SMA Negeri 9 Semarang terdiri dari dua bagian utama : mesin presensi digital dan sebuah PC sebagai server aplikasi web. Masukan berupa data kehadiran didapatkan dari mesin presensi, sedangkan informasi presensi diolah dan disajikan oleh server, keduanya terhubung oleh kabel UTP.

Perangkat lunak dibangun menggunakan bahasa skrip PHP mengikuti susunan kerangka kerja PHP Phalcon, basis data MySQL, aplikasi webserver Nginx, dan lingkungan sistem operasi Ubuntu 14.04. Diagram deployment dari sistem presensi SMAN 9 Semarang ditunjukkan pada Gambar 10.

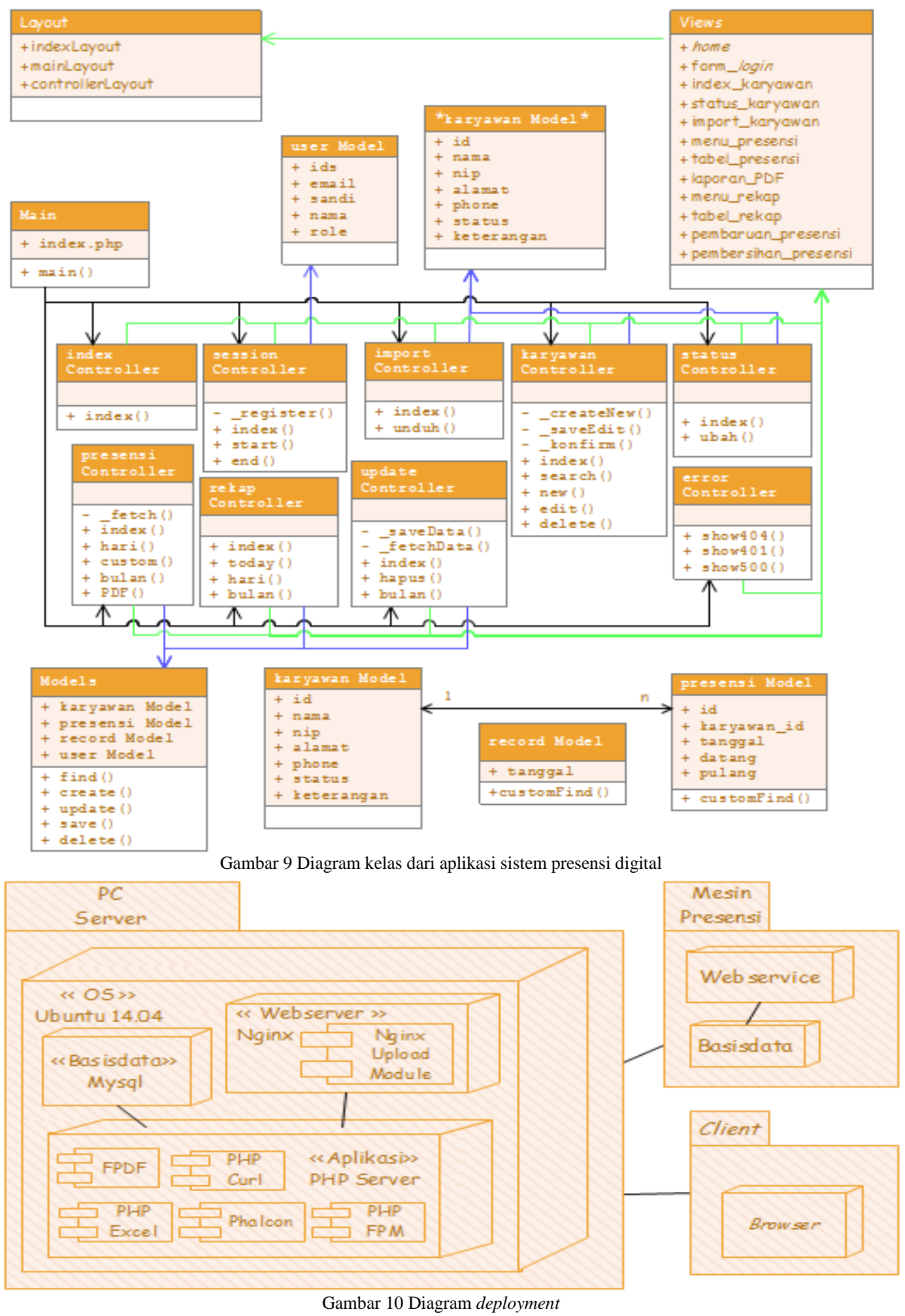




\section{B. Implementasi Aplikasi}

Aplikasi web mengikuti kerangka kerja MVC Phalcon dan menggunakan fungsi autoloader dari Phalcon. Komponen DI mengimplementasikan fungsi Dependency Injection dan Location of Services untuk aplikasi Phalcon. DI juga berfungsi sebagai service container yang menyediakan global instances dari sebuah komponen secara terstruktur dan seragam.

\section{Implementasi Basis Data}

Phalcon menyediakan fungsi yang diperlukan untuk membuat skema tabel dalam basis data. Pembuatan tabel MySQL untuk aplikasi presensi digital SMA Negeri 9 Semarang dilakukan menggunakan kode PHP. Eksekusi kode tersebut dilakukan pada server melalui akses localhost.

\section{Implementasi Webserver}

Pada konfigurasi blok server, diberikan dua alamat IP untuk variabel konfigurasi server_name : 192.168.105.110 yang diakses dari jaringan lokal dan 112.78.39.224 yang diakses dari jaringan publik.

\section{E. Pengujian Kotak Putih}

Pengujian kotak putih dilakukan pada level unit dengan penyelidikan rinci dari logika internal dan struktur kode dalam senarai program. Kasus uji dirancang menggunakan independent-path yang didapatkan dari flow graph. Hasil pengujian kotak putih membuktikan bahwa aplikasi presensi digital SMA Negeri 9 Semarang telah memenuhi standar kelayakan.

\section{F. Pengujian Kotak Hitam}

Pengujian kotak hitam dilakukan dengan cara menguji sistem secara keseluruhan. Data hasil pengujian kebutuhan fungsional pada sistem presensi digital SMA Negeri 9 Semarang disajikan pada Tabel 3.

TABEL III

HASIL UJI KEBUTUHAN FUNGSIONAL

\begin{tabular}{|c|c|c|c|}
\hline FUNGSI & KASUS UJI & KETERANGAN HASIL UJI & \\
\hline \multirow[t]{2}{*}{$\begin{array}{l}\text { 1) } \\
\text { Login dan } \\
\text { Logout }\end{array}$} & $\begin{array}{l}\text { A. } \\
\text { Masukan tidak } \\
\text { valid }\end{array}$ & $\begin{array}{l}\text { Aplikasi dapat memberikan hasil } \\
\text { verifikasi berupa pesan error } \\
\text { bahwa data login tidak valid, dan } \\
\text { kembali pada halaman login }\end{array}$ & $\checkmark$ \\
\hline & $\begin{array}{l}\text { B. } \\
\text { Masukan valid }\end{array}$ & $\begin{array}{l}\text { Aplikasi dapat memberikan hasil } \\
\text { verifikasi berupa pesan selamat } \\
\text { datang beserta nama pengguna, } \\
\text { dan menyajikan index karyawan }\end{array}$ & $\checkmark$ \\
\hline \multirow{2}{*}{$\begin{array}{l}\text { 2) } \\
\text { Lihat data } \\
\text { karyawan }\end{array}$} & A. Pengunjung & Menampilkan pesan error & $\checkmark$ \\
\hline & B. TataUsaha & $\begin{array}{l}\text { Aplikasi menampilkan tabel } \\
\text { karyawan dan form pencarian, } \\
\text { dilengkapi tombol pengelolaan }\end{array}$ & $\checkmark$ \\
\hline \multirow{4}{*}{$\begin{array}{l}\text { 3) } \\
\text { Kelola } \\
\text { data } \\
\text { karyawan }\end{array}$} & A. Baru & $\begin{array}{l}\text { Aplikasi dapat menambahkan } \\
\text { data karyawan baru }\end{array}$ & $\checkmark$ \\
\hline & B. Ubah & Aplikasi dapat mengubah data & $\checkmark$ \\
\hline & C. Hapus & Aplikasi dapat menghapus data & $\checkmark$ \\
\hline & D. Form Hapus & $\begin{array}{l}\text { Aplikasi dapat menghapus } \\
\text { beberapa data karyawan }\end{array}$ & $\checkmark$ \\
\hline
\end{tabular}

\begin{tabular}{|c|c|c|c|}
\hline \multirow{2}{*}{$\begin{array}{l}\text { 4) } \\
\text { Ubah } \\
\text { status } \\
\text { karyawan } \\
\end{array}$} & $\begin{array}{l}\text { A. } \\
\text { tidak valid }\end{array}$ & $\begin{array}{l}\text { Aplikasi memberikan pesan error } \\
\text { bahwa keterangan tidak valid. }\end{array}$ & $\checkmark$ \\
\hline & $\begin{array}{l}\text { B. } \\
\text { Data valid }\end{array}$ & $\begin{array}{l}\text { Aplikasi memberi pesan sukses } \\
\text { berisi nama dan status yang baru. }\end{array}$ & $\checkmark$ \\
\hline \multirow{2}{*}{$\begin{array}{l}\text { 5) } \\
\text { Import } \\
\text { data } \\
\text { karyawan }\end{array}$} & $\begin{array}{l}\text { A. } \\
\text { Masukan tidak } \\
\text { valid }\end{array}$ & $\begin{array}{l}\text { Aplikasi tidak menambahkan / } \\
\text { mengubah data karyawan }\end{array}$ & $\checkmark$ \\
\hline & $\begin{array}{l}\text { B. } \\
\text { Masukan valid }\end{array}$ & $\begin{array}{l}\text { Aplikasi menambahkan } \\
\text { mengubah data karyawan sesuai } \\
\text { dengan tabel pada file xls }\end{array}$ & $\checkmark$ \\
\hline $\begin{array}{l}\text { 6) } \\
\text { Unduh } \\
\text { data } \\
\text { karyawan }\end{array}$ & $\begin{array}{l}\text { Dilakukan oleh } \\
\text { pihak Tata } \\
\text { Usaha }\end{array}$ & $\begin{array}{l}\text { Aplikasi membuat header tabel } \\
\text { dan menulis data karyawan dari } \\
\text { basis data ke dalam file xls lalu } \\
\text { mengirim ke browser pengguna }\end{array}$ & $\checkmark$ \\
\hline $\begin{array}{l}\text { 7) } \\
\text { Presensi } \\
\text { digital }\end{array}$ & $\begin{array}{l}\text { Dilakukan oleh } \\
\text { Karyawan }\end{array}$ & $\begin{array}{l}\text { Mesin presensi digital mampu } \\
\text { melakukan verifikasi dan } \\
\text { menyimpan data hadir berupa } \\
\text { nomor ID dan waktu verifikasi }\end{array}$ & $\checkmark$ \\
\hline \multirow[t]{3}{*}{$\begin{array}{l}8) \\
\text { Pembarua } \\
\mathrm{n} \quad \text { data } \\
\text { presensi }\end{array}$} & $\begin{array}{l}\text { A. } \\
\text { Form tanggal } \\
\text { kosong }\end{array}$ & $\begin{array}{l}\text { Aplikasi mengunduh data } \\
\text { kehadiran dari mesin presensi } \\
\text { dengan kriteria: } \\
\text { - tanggal awal berupa tanggal } \\
\text { terbaru pada basis data server } \\
\text { - tanggal akhir berupa tanggal } \\
\text { saat dilakukan pembaruan }\end{array}$ & $\checkmark$ \\
\hline & $\begin{array}{l}\text { B. } \\
\text { Mengisi form } \\
\text { tanggal }\end{array}$ & $\begin{array}{l}\text { Aplikasi mengunduh data } \\
\text { kehadiran dari mesin presensi } \\
\text { sesuai dengan kriteria tanggal }\end{array}$ & $\checkmark$ \\
\hline & $\begin{array}{l}\text { C. } \\
\text { Pembaruan per- } \\
\text { bulan }\end{array}$ & $\begin{array}{l}\text { Aplikasi mengunduh data } \\
\text { kehadiran dari mesin presensi } \\
\text { dengan kriteria } 10 \text { hari per tahap }\end{array}$ & $\checkmark$ \\
\hline $\begin{array}{l}\text { 9) } \\
\text { Hapus } \\
\text { data } \\
\text { presensi }\end{array}$ & $\begin{array}{l}\text { Dilakukan oleh } \\
\text { pihak Tata } \\
\text { Usaha }\end{array}$ & $\begin{array}{l}\text { Aplikasi melakukan evaluasi } \\
\text { pada tanggal presensi yang } \\
\text { diberikan, dan menghapus data } \\
\text { record yang memiliki presensi } \\
\text { kurang dari } 10 \text { karyawan }\end{array}$ & $\checkmark$ \\
\hline \multirow[t]{4}{*}{$\begin{array}{l}\text { 10) } \\
\text { Lihat } \\
\text { presensi }\end{array}$} & $\begin{array}{l}\text { A. } \\
\text { Index Presensi }\end{array}$ & $\begin{array}{l}\text { Aplikasi menampilkan menu } \\
\text { presensi, form untuk memilih } \\
\text { tanggal presensi, dan tombol } \\
\text { untuk memilih presensi }\end{array}$ & $\checkmark$ \\
\hline & $\begin{array}{l}\text { B. } \\
\text { Presensi Harian }\end{array}$ & $\begin{array}{l}\text { Aplikasi menampilkan tabel } \\
\text { berisi data presensi sesuai } \\
\text { dengan tanggal yang diminta }\end{array}$ & $\checkmark$ \\
\hline & $\begin{array}{l}\text { C. } \\
\text { Presensi } \\
\text { Bulanan }\end{array}$ & $\begin{array}{l}\text { Aplikasi menampilkan tabel } \\
\text { berisi data presensi sesuai } \\
\text { dengan bulan yang diminta }\end{array}$ & $\checkmark$ \\
\hline & $\begin{array}{l}\text { D. } \\
\text { Presensi Custom }\end{array}$ & $\begin{array}{l}\text { Aplikasi menampilkan tabel } \\
\text { berisi data presensi sesuai } \\
\text { dengan batasan tanggal }\end{array}$ & $\checkmark$ \\
\hline \multirow{3}{*}{$\begin{array}{l}11) \\
\text { Lihat } \\
\text { rekap }\end{array}$} & $\begin{array}{l}\text { A. } \\
\text { Rekap hari ini }\end{array}$ & $\begin{array}{l}\text { Memberi pesan error jika data } \\
\text { presensi tidak ditemukan. }\end{array}$ & $\checkmark$ \\
\hline & \begin{tabular}{|l|} 
B. \\
Rekap harian \\
per bulan \\
\end{tabular} & $\begin{array}{l}\text { Menampilkan tabel rekap jika } \\
\text { data tersedia dan menampilkan } \\
\text { pesan jika data tidak tersedia. }\end{array}$ & $\checkmark$ \\
\hline & $\begin{array}{l}\text { C. } \\
\text { Rekap bulan per } \\
\text { tahun }\end{array}$ & $\begin{array}{l}\text { Menampilkan tabel rekap jika } \\
\text { data tersedia dan menampilkan } \\
\text { pesan jika data tidak tersedia. }\end{array}$ & $\checkmark$ \\
\hline $\begin{array}{l}\text { 12) } \\
\text { Laporan } \\
\text { PDF }\end{array}$ & TataUsaha & $\begin{array}{l}\text { Aplikasi menyajikan presensi } \\
\text { bulanan dalam format PDF-A4 }\end{array}$ & $\checkmark$ \\
\hline
\end{tabular}


Pengujian kotak hitam dilakukan pula untuk mengetahui bahwa kebutuhan non-fungsional telah terpenuhi. Hasil pengujian pada kebutuhan non-fungsional sistem presensi digital SMA Negeri 9 Semarang dimuat pada Tabel 4.

TABEL IV

HASIL UJI KEBUTUHAN NON-FUNGSIONAL

\begin{tabular}{|c|c|c|c|}
\hline NAMA & KASUS UJI & \multicolumn{2}{|l|}{ KETERANGAN HASIL UJI } \\
\hline \multirow[t]{2}{*}{$\begin{array}{l}\text { 1) } \\
\text { Hak akses }\end{array}$} & A. Pengunjung & $\begin{array}{l}\text { Hanya menampilkan menu } \\
\text { home, presensi, login, dan } \\
\text { memberikan halaman error saat } \\
\text { pengunjung mengakses menu } \\
\text { yang bukan merupakan haknya }\end{array}$ & $\checkmark$ \\
\hline & B. TataUsaha & Menampilkan semua menu & $\checkmark$ \\
\hline \multirow[t]{6}{*}{$\begin{array}{l}\text { 2) } \\
\text { Praktis dan } \\
\text { Mudah }\end{array}$} & $\begin{array}{l}\text { A-1 } \\
\text { Tombol Baru }\end{array}$ & $\begin{array}{l}\text { Dapat menampilkan dialog box } \\
\text { berupa form untuk mengisi data } \\
\text { karyawan baru }\end{array}$ & $\checkmark$ \\
\hline & $\begin{array}{l}\text { A-2 } \\
\text { Submit Baru }\end{array}$ & $\begin{array}{l}\text { Dapat menambahkan karyawan } \\
\text { baru ke dalam tabel, lengkap } \\
\text { dengan tombol ubah dan hapus } \\
\text { yang berfungsi dengan baik }\end{array}$ & $\checkmark$ \\
\hline & $\begin{array}{l}\text { B-1 } \\
\text { Tombol Ubah } \\
\end{array}$ & $\begin{array}{l}\text { Dapat menampilkan dialog box } \\
\text { (form berisi data karyawan) }\end{array}$ & $\checkmark$ \\
\hline & $\begin{array}{l}\text { B-2 } \\
\text { Submit Ubah }\end{array}$ & $\begin{array}{l}\text { Dapat mengubah karyawan } \\
\text { dalam tabel maupun dialog box } \\
\text { pada tombol ubah dan hapus }\end{array}$ & $\checkmark$ \\
\hline & $\begin{array}{l}\text { C-1 } \\
\text { Tombol Hapus } \\
\end{array}$ & $\begin{array}{l}\text { Dapat menampilkan dialog box } \\
\text { yang memuat data karyawan }\end{array}$ & $\checkmark$ \\
\hline & $\begin{array}{l}\text { C-2 } \\
\text { Submit Hapus }\end{array}$ & $\begin{array}{l}\text { Dapat menghapus karyawan } \\
\text { dalam tabel beserta tombol ubah } \\
\text { dan hapusnya }\end{array}$ & $\checkmark$ \\
\hline $\begin{array}{l}\text { 3) } \\
\text { Desain } \\
\text { Sederhana }\end{array}$ & $\begin{array}{l}\text { Desain dan } \\
\text { Animasi }\end{array}$ & $\begin{array}{l}\text { Aplikasi tidak menggunakan } \\
\text { animasi berlebihan, dan mampu } \\
\text { menggunakan desain dari } \\
\text { Bootstrap }\end{array}$ & $\checkmark$ \\
\hline $\begin{array}{l}\text { 4) } \\
\text { Teknik } \\
\text { penyajian }\end{array}$ & Penyajian Tabel & $\begin{array}{l}\text { Form pencarian berfungsi baik, } \\
\text { dan informasi nama, nip, ID } \\
\text { karyawan dapat ditampilkan }\end{array}$ & $\checkmark$ \\
\hline \multirow[t]{2}{*}{$\begin{array}{l}\text { 5) } \\
\text { Aplikasi } \\
\text { Android }\end{array}$} & $\begin{array}{l}\text { A. } \\
\text { Akses Internet }\end{array}$ & $\begin{array}{l}\text { Aplikasi dapat menjangkau } \\
\text { server dan menyajikan data } \\
\text { statistik sesuai menu yang } \\
\text { dipilih }\end{array}$ & $\checkmark$ \\
\hline & $\begin{array}{l}\text { B. } \\
\text { Akses LAN }\end{array}$ & $\begin{array}{l}\text { Aplikasi dapat menjangkau } \\
\text { server dan menyajikan data } \\
\text { statistik sesuai menu yang } \\
\text { dipilih }\end{array}$ & 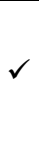 \\
\hline
\end{tabular}

\section{PENUTUP}

\section{A. Kesimpulan}

Dari hasil analisis, perancangan, dan pengujian, dapat disimpulkan :

1. Sistem presensi digital SMA Negeri 9 Semarang melakukan identifikasi karyawan dan mencatat waktu identifikasi sebagai data kehadiran secara digital. Sistem menyimpan dan mengolah data kehadiran tersebut pada sebuah server. Data kehadiran tersebut kemudian disajikan dalam bentuk tabel presensi dan laporan presensi.

2. Sistem presensi digital SMA Negeri 9 Semarang merupakan solusi bagi SMA Negeri 9 Semarang dalam memenuhi kebutuhan presensi digital. Sistem terdiri dari 2 bagian utama, yaitu mesin presensi digital menggunakan pengenalan wajah dan sebuah server untuk aplikasi berbasis web. Aplikasi dibangun menggunakan bahasa skrip PHP, kerangka kerja PHP Phalcon, dan webserver Nginx pada lingkungan sistem operasi Ubuntu 14.04.

3. Sistem presensi digital SMAN 9 Semarang memiliki beberapa fungsi utama : sarana pengelolaan data guru dan karyawan, sarana mendapatkan data kehadiran digital, sarana penyajian informasi kehadiran guru dan karyawan, dan memudahkan dalam pembuatan laporan kehadiran.

4. Penyajian tabel presensi pada aplikasi web bertujuan untuk memudahkan pengguna dalam hal pencarian data, sedangkan penyajian laporan presensi PDF ditujukan untuk memenuhi kebutuhan print-out dokumen.

\section{B. Saran}

Dari hasil analisis, perancangan, dan pengujian, terdapat saran pengembangan berupa :

1. Sistem presensi digital guru karyawan dapat lebih disempurnakan sehingga mampu memberikan informasi yang lebih lengkap : login karyawan, presensi individu, rekap individu, perhitungan waktu terlambat.

2. Dapat ditambahkan modul yang mampu memberikan / menerima data keterangan terperinci untuk pihak guru karyawan yang absen (tidak masuk) oleh karena : sedang dinas luar kota, sakit, cuti, lupa melakukan presensi, atau tanpa keterangan.

3. Dapat ditambahkan menu presensi khusus untuk para penjaga keamanan dan tenaga piket yang terpisah dari presensi guru dan karyawan oleh karena perbedaan sistem : jam kerja (shift) pada hari libur.

4. Sistem presensi digital guru karyawan ini dapat digunakan sebagai model dasar untuk membuat sistem presensi digital siswa dan kurikuler dengan penambahan beberapa modul dan fungsi baru.

\section{DAFTAR PUSTAKA}

[1] Y. Andrika. "Membangun sistem informasi presensi mahasiswa STMIK Atma Luhur Pangkalpinang berbasis web", dalam Makalah Seminar Nasional Teknologi Informasi dan Komunikasi 2013 (SENTIKA 2013). Yogyakarta, 2013.

[2] N.A. Muhammad, F. Samopa, dan R.P. Wibowo. "Pembuatan aplikasi presensi perkuliahan berbasis fingerprint (studi kasus : jurusan sistem informasi Institut Teknologi Sepuluh Nopember Surabaya)", dalam Jurnal Teknik POMITS. Vol.2, No.3, pp. A465-A469, Institut Teknologi Sepuluh Nopember, 2013.

[3] M. Subair. Perancangan Sistem Informasi Presensi Berbasis Sidik Jari Kehadiran Mahasiswa STMIK AMIKOM. Naskah Publikasi Skripsi S1, STMIK AMIKOM, Yogyakarta, 2010.

[4] A. Susanto. Sistem Informasi Manajemen Konsep dan Pengembangannya. Bandung: Lingga Jati, 2004.

[5] Tutorials Point (India) Pvt. Ltd. PHP Tutorial. Diakses: Februari 2015. [Online].

http://www.tutorialspoint.com/php/index.htm 
[6] M.P. Kannygara. Tutorial Menggunakan Phalcon PHP Framework. Diakses: Februari 2015. [Online]. http://antzstudioblog.blogspot.com/search/label/phalcon\%20fra mework

[7] Phalcon Team and contributors. Phalcon PHP Framework Documentation Release 1.3.0. Diakses: Februari 2015. [Online]. http://docs.phalconphp.com/en/latest/index.html

[8] Tutorials Point (India) Pvt. Ltd. MySQL Tutorial. Diakses: Februari 2015.

[Online]. http://www.tutorialspoint.com/mysql/index.htm

[9] Nginx Inc. Nginx Documentation. Diakses: Februari 2015. [Online]. http://nginx.org/en/docs/

[10] H.D. Aguno. Herpiko/enterprise2000-webfetch. Diakses: Februari 2015. [Online]. https://github.com/herpiko/enterprise2000-webfetch

[11] Iserni dan Sheraff. How can I scrape website content in PHP from a website that requires a cookie login?. Diakses: Februari 2015. [Online].

http://stackoverflow.com/questions/13210140/how-can-iscrape-website-content-in-php-from-a-website-that-requires-acookie-lo/13210186\#13210186
[12] Tutorials Point (India) Pvt. Ltd. UML Tutorial. Diakses: Februari 2015. [Online]. http://www.tutorialspoint.com/uml/index.htm

[13] Tutorials Point (India) Pvt. Ltd. JQuery Tutorial. Diakses: Februari 2015. [Online]. http://www.tutorialspoint.com/jquery/index.htm

[14] Bootstrap Team and contributors. Bootstrap. The world's most popular mobile-first and responsive front-end framework. Diakses: Februari 2015. [Online]. http://getbootstrap.com/

[15] Rosa A.S. dan M. Shalahuddin. Rekayasa Perangkat Lunak Terstruktur dan Berorientasi Objek. Cetakan Kedua, Bandung : Informatika, 2014.

[16]C. Kaner. "Exploratory testing, Florida Institute of Technology", dalam Quality Assurance Institute Worldwide Annual Software Testing Conference, Orlando, Florida, November 2006.

[17] Wikimedia Foundation Inc. Black-box testing. Diakses: Februari 2015. [Online]. https://en.wikipedia.org/wiki/Blackbox testing

[18] Wikimedia Foundation Inc. White-box testing. Diakses: Februari 2015. [Online]. https://en.wikipedia.org/wiki/Whitebox_testing 